\title{
Juridical perspectives of interruption of pregnancy with zika virus infection regarding medical, emotional and social consequences
}

\section{Open acess}

${ }^{1}$ Grupo de Estudos sobre o Aborto (GEA).

${ }^{2}$ Núcleo Especializado de Promoção e Defesa dos Direitos da Mulher Defensoria Pública do Estado de São Paulo.

${ }^{3}$ Núcleo de Violência Sexual e Aborto Legal do Hospital Pérola Byington.

${ }^{4}$ Grupo de Trabalho Gênero e Saúde - Associação Brasileira de Saúde Coletiva (ABRASCO).

${ }^{5}$ Departamento de Saúde, Ciclos de Vida e Sociedade - Faculdade de Saúde Pública da Universidade de São Paulo (USP).

${ }^{6}$ Associação Juízes para a

Democracia (AJD).

${ }^{7}$ Sociedade Brasileira de Vigilância de Medicamentos (SOBRAVIME).

${ }^{8}$ Ações Afirmativas em Direito e

Saúde (AADS)

${ }^{9}$ Conselho Federal de Serviço Social (CFSS).

${ }^{10}$ Departamento de Ginecologia -

Faculdade de Medicina de Jundiaí.

\section{Corresponding author:}

jdrezett@gmail.com

Manuscript received: September 2017 Manuscript accepted: October 2017 Version of record online: March 2018
Ana Rita Souza Prata ${ }^{1,2}$, Daniela Pedroso ${ }^{1,3}$, Greice Menezes ${ }^{1,4}$, Jefferson Drezett ${ }^{1,3,5}$, José Henrique Rodrigues Torres ${ }^{1,6}$, José Ruben de Alcântara Bonfim ${ }^{1,7}$, Leila Adesse ${ }^{1,8}$, Maria Elisa dos Santos Braga ${ }^{1,9}$, Monica Kulcsar ${ }^{1}$, Roberto Luiz Corcioli Filho ${ }^{1,6}$, Thomaz Rafael Gollop ${ }^{1,10}$, Yasmin Oliveira Mercadante Pestana ${ }^{1,2}$.

\begin{abstract}
Introduction: The Zika virus was identified in 1947 in Rhesus monkeys in the Republic of Uganda and isolated in humans in 1952 in the same country. Up to 2007 there were few cases of human infection in African and Asian countries. The first outbreak of the Zika virus occurred in Brazil in 2015, becoming a serious public health problem due to the increase in the number of cases of microcephaly in infected pregnant women.
\end{abstract}

Objective: To describe the legal abortion at Zika virus infection during pregnancy regarding medical, emotional and social consequences. perspectives of abortion for the pregnant woman with Zika virus regarding the medical, emotional and social consequences.

Methods: This is a documentary study based on documents about abortion and its outcomes in Brazil. Technical norms, textbooks, indexed articles of Scopus and PubMed, documents extracted from international human rights treaties and conventions, and legal documents on the subject were used. It was decided to direct the text based on the experiences of each theme on abortion and its outcomes in Brazil, with a synthesis of the current scenario.

Results: Recognizing the exceptional nature of this situation, it is sought to confer an interpretation according to the Constitution and Article 128 of the Criminal Code, based on an analogical application, which seeks to protect the physical and mental health of women infected by the Zika virus. It is possible to qualify the practice of abortion in these circumstances as atypical conduct by the state of necessity, excluding the unlawfulness by comparing with articles 23, I and 24 of the Penal Code.

Conclusion: Authorizing the termination of pregnancy after diagnosis of the virus Zika guarantees women the free exercise of their reproductive rights, which is not confused with state imposition of abortion or eugenic practice.

Keywords: zika virus infection, foetal diseases, microcephaly, induced abortion, women's health, public health. 


\section{INTRODUCTION}

The Zika virus was first identified in 1947 in Rhesus monkeys in the Republic of Uganda and isolated in humans in 1952 in the same country. Up to the year 2007 there were few cases of infection registered in humans in African and Asian countries ${ }^{1}$. Only in 2014 was the virus reported in French Polynesia, where there was an unusual increase in the number of cases of malformations of the central nervous system in foetuses and newborns ${ }^{2}$.

The first epidemic outbreak of the Zika virus occurred in Brazil in 2015, rapidly becoming a serious public health problem due to its association with the surprising increase in the number of cases of microcephaly in infected pregnant women ${ }^{2,3}$. Between March 2015 and April 2016, more than 5,000 cases of microcephaly were reported in the country, the majority in the northeast region, 20 times higher than in previous years ${ }^{4}$. In response, in February 2016 the World Health Organization (WHO) declared the situation of the Zika virus as a health emergency of international importance ${ }^{5}$.

The Zika virus is spread by the mosquito Aedes aegypti, which also transmits diseases such as chikungunya fever and dengue fever. In addition to pregnant women being directly contaminated by the mosquito, it has also been established that the disease can be acquired through sexual intercourse with partners contaminated by the Zika virus, even if these partners do not show signs of the disease. Transmission of the virus from pregnant women to the foetus at any time during pregnancy is also documented ${ }^{6}$.

The Zika virus causes an acute, usually selflimiting, febrile illness that rarely requires hospitalization for treatment. It is estimated that only $20 \%$ of people with Zika virus infection have clinical signs and symptoms, which may include low fever, red patches, pruritus, joint pain, muscle aches, headache, redness of eyes, dry cough or vomiting. There is no specific treatment and the symptoms last for a few days. The Zika virus is also a cause of Guillain-Barré syndrome and other relevant neurological diseases, such as myelitis and meningoencephalitis, although these disorders are uncommon. Deaths from Zika virus infection are rare in the literature ${ }^{4}$.

\section{Zika Virus Infection During Pregnancy}

According to WHO, microcephaly is considered when the cephalic perimeter measurment is two or more standard deviations below the mean. In the United States, the public birth defect mapping system estimates that the number of newborns with microcephaly, resulting from different causes, ranges from 2 to 12 cases per 10,000 births $^{7}$. In the absence of maternal infection with the Zika virus, microcephaly occurs in 8.7 per 10,000 live births ${ }^{8}$.

Microcephaly may have different causes, which are classified as primary or secondary. Primary microcephaly is often caused by genetic abnormalities that interfere with brain growth during the first months of foetal development. It is associated with chromosomal, metabolic syndromes or gene mutations. The most common form is true microcephaly, in which no neurological or other abnormalities occur. Secondary microcephaly has perinatal causes, such as hypoxaemia at birth, intracranial haemorrhage or obstetric trauma ${ }^{7}$.

Microcephaly may also be of infectious origin, following meningitis or encephalitis, contamination by chemical agents, or resulting from maternal infection with rubella, syphilis, varicella, toxoplasmosis or cytomegalovirus ${ }^{7}$. This diversity of conditions and aetiologies of microcephaly results in different foetal and newborn consequences, which in some cases does not imply brain damage, intellectual disability or relevant cognitive impairment ${ }^{9}$.

However, newborns with Zika virus infection do not only present microcephaly. Severe neurological damage is present, such as decreased auditory acuity, congenital deafness, excess scalp, arthrogryposis, congenital crooked foot, and dysplasia of the hip joints ${ }^{10,11}$. Ophthalmologic damage is also severe, including diseases such as microphthalmia, anophthalmia, coloboma, cataracts, intraocular calcifications, chorioretinal macular anomalies such as atrophy, pallor, gross abnormalities and retinal haemorrhage, and optic nerve atrophy ${ }^{11}$.

The evidence is overwhelming regarding the brain damage produced by the Zika virus, which is predominantly destructive, irreversible and irreparable, even if qualified care can be provided to the newborn. The findings include cerebral atrophy, white cell, caudate nucleus and cerebellum calcifications, corpus callosum and vermix dysgenesis, and dilation of the cisterna magna. Also included are asymmetry of the cerebral hemispheres, increase of the ventricles and thinning of the cerebral parenchyma $^{12}$.

Studies also found an increased risk of foetal intrauterine growth restriction, impaired placental function, spontaneous abortion up to the 20th week of pregnancy and foetal death stillbirth in infected pregnant women $^{11}$. These conditions have a negative impact on the normal development of the children affected, greatly impairing their quality of life. Therefore, the serious situation presented is that of a congenital Zika syndrome, which is different from the reductionist perception of microcephaly ${ }^{9,13}$.

Facing congenital Zika syndrome involves obstacles and challenges, considering the high incidence of foetal anomalies among infected pregnant women. In the US, a collaborative study between the Centers for Disease Control and Prevention (CDC) and US health departments involving 442 pregnant women with Zika virus infection showed that 271 of them $(61.3 \%)$ were asymptomatic. Twenty-six foetuses or newborns (5.9\%) with congenital anomalies were found, of which $85 \%$ had cerebral anomalies, microcephaly or both. All foetal or newborn compromises occurred in mothers with symptomatic infection or positive serology for the Zika virus either in the first trimester of pregnancy or in the periconceptional period ${ }^{11}$.

However, the data above contrasts sharply with those found in Brazil. For reasons not yet established, pregnant women in the north-east states of Brazil and Rio de Janeiro infected with the Zika virus have foetuses or 
newborns affected more severely and more frequently. In these regions, foetal death occurred in $7 \%$ of the cases, with $46 \%$ of foetuses or newborns presenting with congenital anomalies. Severe cranial and encephalic anomalies were found in $42 \%$ of cases. In addition, Brazilian researchers observed that foetal or newborn involvement occurred at any time during gestation. In fact, central nervous system abnormalities have been found in foetuses infected with the Zika virus even at the 39th week of pregnancy ${ }^{14}$.

Given that there is no limited period of pregnancy during which Zika virus foetal contamination may occur, the anguish experienced by the pregnant women in this situation generates enormous psychicological and emotional suffering. In such cases, the defense of the decision to interrupt pregnancy or not, which may or may not be taken prior to the diagnosis of foetal anomalies, favours the sexual and reproductive rights of women ${ }^{15,16}$.

The intense psychological distress of pregnant women with the infection can put their mental health at risk, with the possibility of generating conditions of social and psychic vulnerability for the rest of their lives, since there is no prognosis for repair and no public policies regarding the future of the child and the dignified life of the woman. This context carries similarities to the impacts of subjective torture situations as it places the pregnant woman at permanent risk of physical and psychic disruption, forcibly unable to make autonomous decisions about her body and her life $\mathrm{e}^{15,16}$.

Given the fragile health conditions and social determinants, such as poverty added to the massive presence of the vector, Brazil has become a propitious country for the consolidation of the Zika virus. The demands of care are increasing and it is becoming necessary that actions are carried out with the purpose of prevention and control of the problem in the face of a new public health reality ${ }^{3}$.

\section{Zika Virus And Pregnancy Interruption}

The Brazilian State's omission regarding the guarantee of women's sexual and reproductive rights is well known. The need to ensure the free exercise of women's sexual and reproductive rights has already been addressed in General Recommendation No. 24, during the Convention on the Elimination of All Forms of Discrimination against Women (CEDAW) in 1999, which states: "Prioritize the prevention of unwanted pregnancies through family planning and sex education and reduce maternal mortality rates through risk-free services and prenatal care. As far as possible, it should amend legislation criminalizing abortion in order to abolish the punitive provisions imposed on women who undergo abortions" ${ }^{\prime 17}$.

In a common context, disrespect for the abovementioned fundamental rights violates other rights, such as the right to information, intimacy, freedom, among others, according to the opinion of the Attorney General of the State in Direct Action of Unconstitutionality (ADI) $n^{\circ}$ 5,097 , not yet judged in the Federal Supreme Court (STF). This situation is aggravated when an epidemic of a virus, such as Zika, occurs, which, according to all the evidence, interferes directly with a woman's gestation.
It is known that the Penal Code criminalizes abortion, however, it also allows, since its promulgation, the termination of pregnancy in cases of risk to the life of the pregnant woman and where a pregnancy results from sexual violence (article 128, I and II) 18. The STF acknowledged another hypothesis, allowing the interruption of pregnancy in anencephalic foetuses, guaranteeing interpretation according to the Federal Constitution, in the Arrangement of Non-compliance with Fundamental Precept (ADPF) n. 54 ${ }^{19}$. Just as one could not have imagined the detection of anencephaly at the time of the amendenment to the Penal Code, cases in which the Zika virus epidemic could bring such devastating and uncertain consequences to the foetus could not have been predicted.

The decisions to allow the termination of a pregnancy in the three cases mentioned above are all based on women's rights, recognizing that a woman do not lose their status as a person due to being pregnant, as in the case of Artavia Murillo and Others (Fertilización in vitro) v. Inter-American Court of Human Rights. The guarantee of the life and health of women should prevail, meaning health as the state of complete physical, mental and social well-being, and not only the absence of disease, as established by the World Health Organization, since 1946. This was the legislator's decision in the promulgation of Decree-Law no. $3914 / 1941^{20}$ and of the STF in ADPF $n^{\circ}$ $54^{19}$.

Recently, in the judgment of the specific case referring to Habeas Corpus (HC) $n^{\circ} 124.306 / \mathrm{RJ}$, the STF conferred interpretation according to the Constitution to articles 124 to 126 of the Penal Code. It was decided not to criminalize abortion during the first trimester of pregnancy, stating that in this case, criminalization would violate women's fundamental rights, their autonomy, the principle of proportionality, the physical and psychological integrity of the pregnant woman, the principle of equality and the right to access to medical care ${ }^{21}$.

Women infected with the Zika virus who are pregnant suffer from the lack of information and the uncertainty of what they will face in the future. This state of ignorance about their own future and the lack of autonomy in making decisions can generate severe psychic suffering, comparable to torture. Furthermore, in view of the criminalization of the termination of pregnancy, women are subjected to degrading treatment and ill-treatment by the health services when they resort to illegal termination of pregnancy ${ }^{22}$.

Recognizing the exceptional nature of this situation, it is necessary to confer an interpretation according to the Constitution and Article 128, items I and II of the Criminal Code, based on an analogical application that seeks to protect the physical and mental health of women infected by the Zika virus. In the same sense, it is possible to describe the practice of interrupting pregnancy in these circumstances as an atypical conduct by the state of necessity, excluding unlawfulness by comparing with articles 23, I and 24 of the Penal Code ${ }^{18}$.

In this scenario of uncertainties it is not possible to predict the number of pregnant women who will be infected by the Zika virus or how many will present severe 
foetal or neonatal damage at the end of gestation. Likewise, it is not possible to predict the evolution of the epidemic, and it is prudent to acknowledge both its aggravation and its resurgence, depending on the effectiveness of the measures that will be adopted in an attempt to control the epidemic ${ }^{9}$.

To authorize the termination of pregnancy, after diagnosis of Zika virus infection, is to guarantee to women, especially those in situations of greater vulnerability, the free exercise of their reproductive rights, which is not to be confused with the State's imposition of abortion or its eugenic practice. On the contrary, it is ensuring that women will exercise a conscientious and responsible motherhood with the support of the State, if they so wish.

\section{REFERENCES}

1. Hayes EB. Zika virus outside Africa. Emerg Infect Dis. 2009;15(9):1347-50. DOI: http://dx.doi.org/10.3201/eid1509.090442

2. loos S, Mallet HP, Goffart IL, Gauthier V, Cardoso T, Herida M. Current Zika virus epidemiology and recent epidemics. Med Mal Infect. 2014;44(7):302-7. DOI: http://dx.doi.org/10.1016/j.medmal.2014.04.008

3. Schram PCF. Zika virus and public health. J Hum Growth Dev. 2016;26(1):7-8. DOI: http://dx.doi.org/10.7322/jhgd.114415

4. Brasil. Ministério da Saúde. Secretaria de Atenção à Saúde. Protocolo de atenção à saúde e resposta à ocorrência de microcefalia. Brasília: Ministério da Saúde, 2016; p.42.

5. Organización Mundial de la Salud. Declaración de la OMS sobre la primera reunión del Comité de Emergencia del Reglamento Sanitario Internacional (2005) sobre el virus del Zika y el aumento de los trastornos neurológicos y las malformaciones congénitas. Geneva: Organización Mundial de la Salud; 2016.

6. Hills SL, Russell K, Hennessey M, Williams C, Oster AM, Fischer M, et al. Transmission of vírus Zika through sexual contact with travellers to areas of ongoing transmission - continental United States, 2016. Morb Mortal Wkly Rep. 2016;65(8):215-6. DOI: http://dx.doi.org/10.15585/mmwr.mm6508e2

7. Organización Mundial de la Salud. Vigilancia de anomalías congénitas: manual para gestores de programas. Geneva: OMS, 2015.

8. Cragan JD, Isenburg JL, Parker SE, Alverson CJ, Meyer RE, Stallings EB, et al. Population based microcephaly surveillance in the United States. 2009 to 2013: An analysis of sources of variation. Birth Defects Res A Clin Mol Teratol. 2016;106(11):972-82. DOI: http://dx.doi.org/10.1002/bdra.23587

9. Drezett J, Gollop TR. O vírus Zika: uma nova e grave ameaça para a saúde reprodutiva das mulheres. Reprod Clim. 2016;31(1):1-4. DOI: http://dx.doi.org/10.1016/j.recli.2016.05.00

10. Ventura CV, Maia M, Bravo-Filho V, Góis AL, Belfort Jr R. Zika virus in Brazil and macular atrophy in a child with microcephaly. Lancet. 2016;387(10015):228. DOI: http://dx.doi.org/10.1016/S0140-6736(16)00006-4

11. Honein MA, Dawson AL, Petersen EE, Jones AM, Lee EH, Yazdy MM, et al. Birth defects among fetuses and infants of US women with evidence of possible Zika virus infection during pregnancy. JAMA. 2017;317(1):59-68. DOI: http://dx.doi.org/10.1001/jama.2016.1900

12. Melo ASO, Malinger G, Ximenes R, Szejnfeld PO, Alves SS, Filippis AB. Zika virus intrauterine infection causes fetal brain abnormality and microcephaly: tip of the iceberg? Ultrasound Obstet Gynecol. 2016;47(1):6-7. DOI: http://dx.doi.org/10.1002/uog.15831

13. Rasmussen SA, Jamieson DJ, Honein MA, Petersen LR. Zika Virus and birth defects - reviewing the evidence for causality. N Engl J Med. 2016;374:1981-7. DOI: http://dx.doi.org/10.1056/NEJMsr1604338

14. Brasil P, Pereira Jr JP, Moreira ME, Ribeiro Nogueira RMR, Damasceno L, Wakimoto M, et al. Zika virus infection in pregnant women in Rio de Janeiro. N Engl J Med. 2016;375:2321-34. DOI: http://dx.doi.org/10.1056/NEJMoa1602412

15. Zanello V, Porto M. Aborto e (não) desejo de maternidade(s): questões para a Psicologia. Brasília: Conselho Federal de Psicologia, 2016.

16. Conselho Regional de Psicologia de São Paulo. Documento de Orientação CRP SP nº 01/2016. Documento de orientação frente ao atendimento de mulheres em situação de interrupção de gravidez. São Paulo: Conselho Regional de Psicologia de São Paulo; 2016.

17. Brasil. Presidência da República. Casa Civil. Decreto $n^{\circ} 4.377$, de 13 de setembro de 2002. Promulga a Convenção sobre a Eliminação de Todas as Formas de Discriminação contra a Mulher, de 1979, e revoga o Decreto no 89.460, de 20 de março de 1984. [cited 2018 jan 19] Available from: http://www.planalto.gov.br/ccivil_03/decreto/2002/d4377.htm. 
18. Delmanto C, Delmanto R, Delmanto-Jr R, Delmanto FMA. Código penal comentado. $8^{a}$ ed. São Paulo: Saraiva; 2010.

19. Brasil. Supremo Tribunal Federal (STF). Questão de ordem na arguição de descumprimento de preceito fundamental. Brasília [cited 2013 abr 20] Available from: http://www.stf.jus.br/portal/jurisprudencia/ listarJurisprudencia.asp?s1=\%28anencefalia\%29\&base=baseAcordaos\&url=http://tinyurl.com/c63gqkq.

20. Brasil. Presidência da República. Casa Civil. Subchefia para Assuntos Jurídicos. Decreto-Lei $N^{\circ} 3.914$, de 9 de dezembro de 1941. Lei de introdução do Código Penal (decreto-lei n. 2.848, de 7-12-940) e da Lei das Contravenções Penais (decreto-lei n. 3.688, de 3 outubro de 1941). [cited 2013 abr 20] Available from: http://www.planalto.gov.br/ccivil_03/decreto-lei/del3914.htm.

21. Brasil. Supremo Tribunal Federal. Habeas Corpus 124.306 Rio de Janeiro. Voto-Vista. Brasília: Supremo Tribunal Federal; 2016. [cited 2013 abr 20] Available from: https://www.conjur.com.br/dl/hc-voto-abortoIrb.pdf.

22. Drezett J. Aborto em situações de violência sexual: o que representa a experiência do Hospital Pérola Byington? Juizes Democ. 2017:17(75):3.

\section{Resumo}

Introdução: O vírus Zika foi identificado em 1947 em macacos Rhesus na República de Uganda e isolado em seres humanos, em 1952, no mesmo país. Até 2007 registram-se poucos casos da infecção em humanos em países africanos e asiáticos. O primeiro surto epidêmico do vírus Zika ocorreu no Brasil, em 2015, tornando-se grave problema de saúde pública devido a elevação do número de casos de microcefalia em gestantes infectadas.

Objetivo: Descrever as perspectivas jurídicas do aborto para a gestante com vírus Zika a partir das consequências médicas, emocionais e sociais.

Método: Trata-se de estudo documental realizado a partir de documentos sobre o aborto e seus desfechos no Brasil. Utilizaram-se normativas técnicas, livros-texto, artigos em bases indexadas do Scopus e PubMed, documentos extraídos de tratados e convenções internacionais de Direitos Humanos e documentos jurídicos acerca da temática. Optou-se por direcionar o texto a partir das experiências de cada temática sobre o aborto e seus desfechos no Brasil, com síntese do cenário atual.

Resultados: Reconhecendo o caráter excepcional dessa situação, busca-se conferir uma interpretação conforme a Constituição e o artigo 128 do Código Penal, a partir de uma aplicação analógica, que busque tutelar a saúde física e psíquica das mulheres contaminadas pelo vírus Zika. É possível qualificar a prática do aborto nessas circunstâncias como conduta atípica pelo estado de necessidade, excluindo a ilicitude por equiparação aos artigos 23, I e 24, do Código Penal.

Conclusão: Autorizar a interrupção da gravidez após o diagnóstico do vírus Zika garante às mulheres o livre exercício dos seus direitos reprodutivos, o que não se confunde com imposição estatal do aborto ou prática eugênica.

Palavras-chave: infecção pelo zika vírus, doenças fetais, microcefalia, aborto induzido, saúde da mulher, saúde pública.

${ }^{-}$The authors (2018), this article is distributed under the terms of the Creative Commons Attribution 4.0 International License (http://creativecommons.org/licenses/by/4.0/), which permits unrestricted use, distribution, and reproduction in any medium, provided you give appropriate credit to the original author(s) and the source, provide a link to the Creative Commons license, and indicate if changes were made. The Creative Commons Public Domain Dedication waiver (http://creativecommons.org/publicdomain/ zero/1.0/) applies to the data made available in this article, unless otherwise stated. 